\title{
Circulating immune complexes in patients with breast cancer
}

\author{
KLAUS HOFFKEN, IAN D MEREDITH, R ADRIAN ROBINS, ROBERT W BALDWIN, \\ CHRISTOPHER J DAVIES, ROGER W BLAMEY
}

\begin{abstract}
Summary
In a retrospective study in women with breast cancer circulating immune complex levels were measured by radioimmunoprecipitation with ${ }^{125} \mathrm{I}-\mathrm{C} 1 \mathrm{q}$. Before operation all the patients showed plasma immune complex levels significantly higher than those in controls. Twelve months after mastectomy patients identified clinicopathologically as having a good prognosis had almost normal levels of immune complexes. By contrast, patients with detectable dissemination on diagnosis or those who died within 22 months after mastectomy had significantly raised plasma levels. The tumour-specific nature of the immune complexes detected remains to be shown and suggestions about the applicability of this test not only for prognosis but also for monitoring the course of malignant diseases need to be confirmed by further investigations.
\end{abstract}

\section{Introduction}

In 1969 Hellström and Hellström ${ }^{1}$ showed the ability of sera from tumour-bearing animals to block cell-mediated immunity in vitro. Subsequently, these "blocking factors" have been found in various experimental animal tumours and also in the sera of patients with cancer. ${ }^{23}$ The observation that blocking factors disappeared rapidly after spontaneous regression or excision in both experimental animal systems and malignancies ${ }^{1+}$ suggested that tumour-specific immune complexes may be implicated in this phenomenon. Thus in animals or patients rendered tumour free tumour-specific antigens are eliminated and antibody activity becomes demonstrable. Evidence to support the immune-complex nature of blocking activity has been provided in several animal studies, ${ }^{5-7}$ which suggests that tumour-specific antigen-antibody complexes play a biologically important part in the control of tumour growth.

In 1973 Mukojima et $a l^{8}$ reported a patient with Burkitt's lymphoma in clinical remission whose antibody titre to EpsteinBarr-virus-associated membrane antigens decreased while complement consumption simultaneously increased; the increase in complement consumption was induced by complement fixation to immune complexes. These phenomena preceded a clinically detectable tumour recurrence by eight months. Subsequently, efforts were made to detect soluble immune complexes in the sera of patients with cancer by methods well established in the serology of rheumatoid diseases. •

Using a radioimmunoprecipitation assay based on binding of ${ }^{125} \mathrm{I}-\mathrm{Clq}$ to soluble immune complexes, Rossen et al ${ }^{9}$ screened

\footnotetext{
Cancer Research Campaign Laboratories, University of Nottingham, Nottingham NG7 2RD

KLAUS HOFFKEN, MD, visiting research fellow

IAN D MEREDITH, LIBIOL, research technician

R ADRIAN ROBINS, PHD, research officer

ROBERT W BALDWIN, PHD, FRCPATH, professor of tumour biology

CHRISTOPHER J DAVIES, FRCS, surgical research fellow

Department of Surgery, City Hospital, Nottingham

ROGER W BLAMEY, MD, FRCS, reader in surgery
}

patients with various human malignancies. They observed that patients with evident disease had high $\mathrm{Clq}$ binding values more often than those with no detectable tumour, although both groups had higher $\mathrm{Clq}$ binding values than controls. $N$ oreover, a direct correlation with the stage of disease seemed to exist in patients with melanoma and cancer of the colon. Similar results were obtained in patients with melanoma by Cano et al, ${ }^{10}$ using a modified Clq-binding assay. In most patients with Hodgkin's disease sera containing immune complexes could be detected, ${ }^{11} 1$ but the evidence on correlation to stage and systemic symptoms remained conflicting. Heimer and Klein ${ }^{13}$ detected complement consumption activity in the sera of $60^{\circ}$ of patients with Burkitt's lymphoma and $54 \%$ of patients with nasopharyngeal carcinoma.

We describe here evidence that the measurement of soluble circulating immune complexes by radioimmunoprecipitation with ${ }^{125} \mathrm{I}-\mathrm{Clq}$ may help in determining the prognosis of individual patients with primary operable breast cancer and in monitoring the course of the disease.

\section{Patients and methods}

Plasma taken from 22 patients with primary operable breast cancer for a prospective study of the prognostic value of the leucocyte migration inhibition test (C J Davies et al; to be published) was stored at $-20^{\circ} \mathrm{C}$ and used in this retrospective study. The patients were divided into good and poor prognosis groups on the basis of findings on regional lymph node biopsy (low axilla, apex of axilla, and internal mammary chain) performed at simple mastectomy. The 10 patients with a good prognosis had no histological evidence of metastatic tumour in the lymph nodes. The seven with a poor prognosis had metastatic tumour in lymph nodes from the apex of the axilla or the internal mammary chain, or both. Samples taken before operation and 12 months after operation were tested in both these groups of patients. In addition preoperative samples and the last available sample before death were tested in five patients who died 10 to 22 months after operation. Ten apparently healthy age-matched women (nine hospital staff and one relative) served as controls.

Clq was purified from a pool of normal human sera by the method of Yonemasu and Stroud. ${ }^{14}$ Its purity was checked immunoelectrophoretically. Radioiodination of $\mathrm{Clq}$ was performed with lactoperoxidase according to the method of Heusser et al,,$^{15}$ giving a specific activity of about $1 \mu \mathrm{Ci} / \mu \mathrm{g} \mathrm{Clq}$. The results described here were achieved with freshly labelled ${ }^{125} \mathrm{I}-\mathrm{Clq}$, stored no longer than two weeks at $-20^{\circ} \mathrm{C}$.

Plasma samples from patients and controls were stored at $-20^{\circ} \mathrm{C}$ until tested and centrifuged at $105000 \mathrm{~g}$ for 60 minutes at $4^{\circ} \mathrm{C}$ before use to sediment any insoluble material; the lipid layer on top of the centrifuged samples was discarded. Immune complexes were measured by the modified ${ }^{125} \mathrm{I}-\mathrm{Clq}$ binding test according to the method of Zubler et al. ${ }^{16} 17$

Briefly, $0.05 \mathrm{ml}$ of unheated plasma was incubated for 30 minutes at $37^{\circ} \mathrm{C}$ together with $0.1 \mathrm{ml}$ of $0 \cdot 2-\mathrm{M} \mathrm{Na}$-ethylenediamine tetraacetic acid, $\mathrm{pH} 7.5$, in polystyrene tubes. Thereafter $0.05 \mathrm{ml}(0.1 \mathrm{~kg})$ of ${ }^{125} \mathrm{I}-\mathrm{Clq}$ in veronal buffered saline, $\mathrm{pH} 7 \cdot 2$, containing $1 \%$ bovine serum albumin and $1.0 \mathrm{ml}$ of $3 \% \mathrm{w} / \mathrm{v}$ polyethylene glycol molecular weight 6000 (BDH Chemicals Ltd), was added and the tubes were transferred into an ice bath. Polyethylene glycol was dissolved in borate buffered saline $(0 \cdot 1-\mathrm{M}$ boric acid, $0 \cdot 025-\mathrm{M}$ disodium tetraborate, $0.075-\mathrm{M} \mathrm{NaCl}, \mathrm{pH} 8.3$ ). After the second incubation the samples were centrifuged at $1500 \mathrm{~g}$ for 20 minutes at $4^{\circ} \mathrm{C}$ and the supernatant completely discarded. Precipitated radioactivity was measured in a gamma-spectrometer (LKB, Wallac) and results were expressed as percentage ${ }^{125} \mathrm{I}-\mathrm{Clq}$ precipitated compared with the radioactivity precipitated with trichloracetic acid $(0.1 \mathrm{ml}$ normal serum, $0.05 \mathrm{ml}{ }^{125}$ I-Clq, $1.0 \mathrm{ml} 20 \%$ trichloracetic acid). Heataggregated human $\gamma$-globulins $\left(63^{\circ} \mathrm{C}\right.$ for 20 minutes) mixed with 
equal amounts of normal human serum were used for positive controls; and one normal human serum, having shown normal ${ }^{125} \mathrm{I}-\mathrm{C} 1 \mathrm{q}$ binding activity, served as a negative control throughout all tests. All tests were done in duplicate.

\section{Results}

The figure shows the distribution of ${ }^{125} \mathrm{I}-\mathrm{C} 1 \mathrm{q}$ binding activities in the plasma of controls, patients with good and bad prognoses, and the patients who died within 22 months of mastectomy. The horizontal line drawn at $8 \%$ represents the $\mathrm{Clq}$ binding activity in normal sera, as reported by Zubler et al ${ }^{16}$; we confirmed this value by a series of 18 tests on sera from healthy young adults, which gave a mean Clq binding activity of $7 \cdot 85 \% \pm 0 \cdot 34$. The table gives the related $P$ values as evaluated by Student's $t$ test.

Preoperative plasma samples from all three groups of women with breast cancer showed significantly higher $\mathrm{Clq}$ binding activity than control samples. Twelve months after mastectomy the binding activity in the women with a good prognosis had decreased to almost normal. By contrast, the 12-month levels of the women with a poor prognosis and of patients who died were significantly higher than those in the women with a good prognosis. The preoperative levels of circulating immune complexes tended to be higher in the women with a poor prognosis and highest in those who subsequently died $(P<0.05)$ compared with those in patients with no detectable lymph node metastases at the time of mastectomy. A similar pattern was observed in the 12-month postoperative plasma levels.

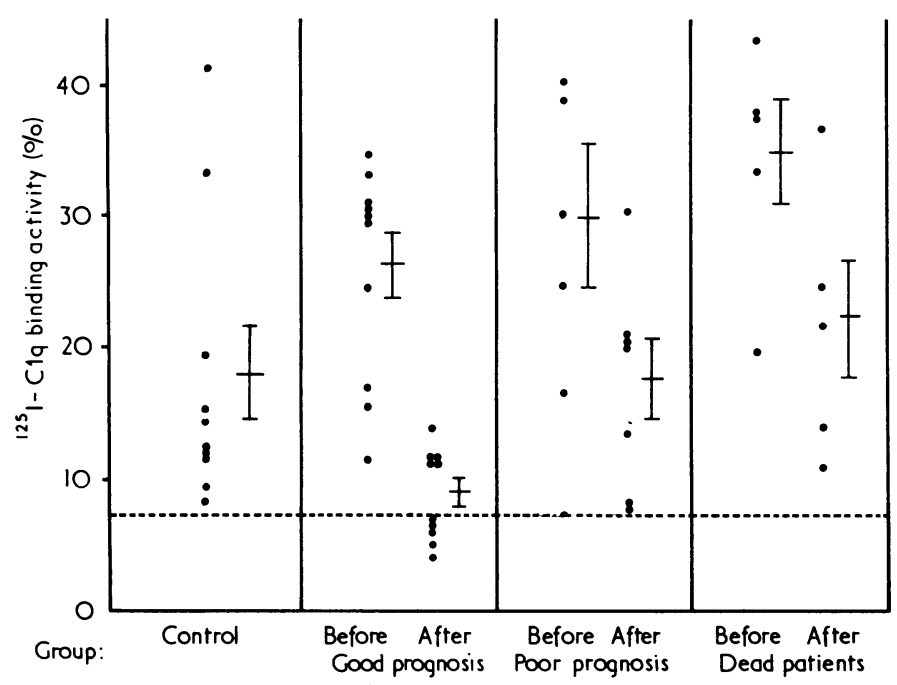

Mean ${ }^{125} \mathrm{I}-\mathrm{Clq}$ binding activities $( \pm \mathrm{SE}$ ) in women with breast cancer before and 12 months after operation according to clinicopathological staging. Horizontal dotted line at $8 \%$ represents binding activity in normal sera (see text).

\section{Discussion}

Before operation all the patients with breast cancer showed high levels of immune complexes. This supports the suggestion that tumour-specific antigens are shed from the tumour into the circulation, where they evoke a specific antibody response that can be shown by methods measuring antigen-antibody complexes. Twelve months after mastectomy there were significant differences in immune complex levels between patients with a good prognosis (no evidence of dissemination to the regional lymph nodes) and both those who died within 22 months of surgery and those with a poor prognosis (extensive lymph node involvement). A possible explanation for these findings is that 12 months after excision of the primary tumour the patients with a good prognosis had insufficient residual tumour to release enough antigen for the formation of detectable quantities of immune complex. By contrast, patients expected to have considerable residual tumour may still have shed sufficient antigens to give rise to immune complex production.

Our data have several limitations. The control group did not consist of proved healthy individuals-for example, blood donors. Therefore the mean $\mathrm{Clq}$ binding activity in this group does not reflect an appropriate normal range-for instance, the control with $\mathrm{Clq}$ binding activity of $41.6 \%$ had suffered from jaundice.

Although two of the 10 age-matched controls showed abnormally high binding activity (greater than $20 \%$ ), 16 of the 22 patients also had activities greater than $20 \%$ before operation. Since various non-malignant diseases cause circulating immune complexes-for example, rheumatoid diseases, influenza, liver diseases, neurological diseases, renal diseases, dermatological diseases-the increase in $\mathrm{Clq}$ binding activity detected cannot be ascribed with certainty to tumour-specific immune complexes. Clinical conditions known to interfere with immune complex measurement were not specifically considered in the present study, and therefore a prospective study is necessary to confirm our preliminary findings. Nevertheless, the $\mathrm{Clq}$ binding activity measured in patients with breast cancer so far seems to correlate much better with other prognostic indicators, such as lymph node status, and clinical outcome than studies of general immunocompetence or cellular reactivity to tumour extracts, which were also carried out in these patients (C J Davies $e t a l$; to be published).

Additional investigations are under way to determine whether the measurement of immune complexes contributes only to the determination of prognosis or whether it is also helpful in monitoring the course of malignant tumours. Some of the patients with a good prognosis showed increased levels of C1q binding activity 18 and 24 months after mastectomy (data not shown), but these women have not been followed long enough to determine whether this is caused by an impending clinical relapse.

Further studies will try to determine whether the immune complexes detected are tumour specific, using immuno-

Plasma $\mathrm{C1} q$ binding activities in women with breast cancer and comparison of values in each group before and after operation

\begin{tabular}{|c|c|c|c|c|c|c|c|c|c|c|c|}
\hline & & & & & \multirow{2}{*}{ Controls } & \multicolumn{2}{|c|}{ Good prognosis } & \multicolumn{2}{|c|}{ Poor prognosis } & \multicolumn{2}{|c|}{$\begin{array}{l}\text { Poor prognosis with death } \\
\text { within } 22 \text { months }\end{array}$} \\
\hline & & & & & & Before & After $\dagger$ & Before & After $\dagger$ & Before & After $\ddagger$ \\
\hline \multicolumn{3}{|c|}{$\begin{array}{l}\text { No of patients } \% \\
\text { Mean }( \pm \text { SE) Ciq binding activity }(\%)\end{array}$} & $\because$ & 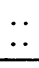 & $\begin{array}{c}10 \\
17 \cdot 9^{ \pm} \pm 3 \cdot 5 \\
\end{array}$ & \multicolumn{2}{|l|}{$26 \cdot 2+2 \cdot 6$} & \multicolumn{2}{|l|}{$29.9 \pm 5.5$} & \multicolumn{2}{|l|}{$34 \cdot 9 \pm 4 \cdot 1$} \\
\hline \multirow{2}{*}{\multicolumn{4}{|c|}{ 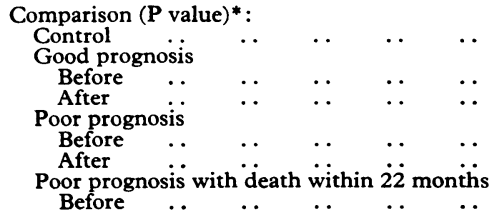 }} & $\cdots$ & & $<0.05$ & $<0.025$ & $<0.05$ & NS & $<0.01$ & NS \\
\hline & & & & $\begin{array}{l}\cdots \\
\cdots \\
\cdots\end{array}$ & & & $<0.0005$ & $\begin{array}{l}\text { NS } \\
<0.0005\end{array}$ & $\begin{array}{l}<0.05 \\
<0.005 \\
<0.05\end{array}$ & $\begin{array}{c}<0.05 \\
<0.0005 \\
\text { NS } \\
<0.005\end{array}$ & $\begin{array}{c}\text { NS } \\
<0.0025 \\
\text { NS } \\
\text { NS }\end{array}$ \\
\hline $\begin{array}{ll}\text { Before } & \\
\text { After } & \end{array}$ & .. & $\begin{array}{ll}. & . \\
. & .\end{array}$ & $\because$ & .. & & & & & & & $<0.05$ \\
\hline
\end{tabular}

*Student's $t$ test. †Sample taken 12 months after mastectomy. $\quad$ LLast sample before death. NS $=$ Not significant. 
absorption on to tumour cell lines, low $\mathrm{pH}$ dissociation of active serum samples, and subsequent antibody tests or titration studies with soluble tumour extracts, since it is known that $\mathrm{Clq}$ binding activity decreases in antigen excess. ${ }^{18}$ In animal studies our findings and those of others ${ }^{19}$ show that low levels of immune complexes have to be interpreted in the light of the patient's clinical state, since a significant drop in detectable serum immune complexes occurs in animals with a large tumour burden shortly before death. This probably reflects a shift in antigen-antibody balance to high antigen excess. Thus, low levels of $\mathrm{Clq}$ binding activity can occur when no tumour is left or a large tumour burden is present.

This study was supported by a block grant from the Cancer Research Campaign. KH is supported by the Deutsche Forschungsgemeinschaft (Ho 692/1). We thank M R Price and V E Preston for their continuous help and advice in setting up the Clq test.

\section{References}

${ }^{1}$ Hellström, I, and Hellström, K E, International fournal of Cancer, 1969, $4,587$.
2 Hellström, K E, and Hellström, I, Advances in Immunology, 1974, 18, 209. ${ }^{3}$ Baldwin, R W, and Robins, R A, Current Topics in Microbiology and Immunology, 1975, 72, 21.

4 Hellström, I, and Hellström, K E, Cancer (Philadelphia), 1974, 34, 1461

${ }^{-}$Sjögren, H O, et al, Proceedings of the National Academy of Sciences of the United States of America, 1971, 68, 1372.

${ }^{6}$ Baldwin, R W, Price, M R, and Robins, R A, Nature New Biology, 1972, 238, 185.

' José, D G, and Seshadri, R, International fournal of Cancer, 1974, 13, 824.

8 Mukojima, T, Gunvén, P, and Klein, G, Fournal of the National Cancer Institute, 1973, 51, 1319.

${ }^{9}$ Rossen, R D, and Reisberg, M A, Proceedings of the American Association of Cancer Research, 1976, 17, 28.

10 Cano, P, et al, Proceedings of the American Association of Cancer Research, 1976, 17, 74 .

11 Amlot, P L, Slaney, J M, and Williams, B D, Lancet, 1976, 1, 449.

12 Kávai, H, et al, Lancet, 1976, 1, 1249.

13 Heimer, R, and Klein, G, International fournal of Cancer, 1976, 18, 310.

14 Yonemasu, K, and Stroud, R H, fournal of Immunology, 1971, 106, 304.

${ }^{15}$ Heusser, C, et al, fournal of Immunology, 1973, 110, 820.

16 Zubler, R H, et al, fournal of Immunology, 1976, 116, 232.

17 Zubler, R H, and Lambert, P H, in In Vitro Methods in Cell-Mediated and Tumour Immunity, ed B R Bloom and J R David, p 565. New York, Academic Press, 1976.

18 Nydegger, U E, et al, Fournal of Clinical Investigation, 1974, 54, 297.

19 Jennette, J C, and Feldman, J D, fournal of Immunology. In press.

(Accepted 18 May 1977)

\title{
BK antibody and virus-specific $\operatorname{IgM}$ responses in renal transplant recipients, patients with malignant disease, and healthy people
}

\author{
AUDREY J E FLOWER, J E BANATVALA, I L CHRYSTIE
}

British Medical fournal, 1977, 2, 220-223

\section{Summary}

Haemagglutination-inhibition (HAI) antibodies to BK virus, including BK-virus-specific IgM, were determined before and after renal transplantation in 20 patients, in 57 patients with malignant disease, and in 66 healthy controls. Before transplantation 11 of the renal transplant recipients were seronegative, but eight later seroconverted, two before and six after transplantation. Twenty of the patients with malignant disease and 22 controls were also seronegative. The geometric mean titre of BK HAI antibodies was significantly higher among transplanted patients $(1 / 180)$ than among controls (1/90). BK-virus-specific IgM antibody was detected in seven renal transplant recipients, six patients with malignant disease, and 13 healthy controls.

In transplant recipients BK-virus-specific IgM antibody usually persisted throughout the duration of the study, and studies on controls from whom second serum samples were available suggested that they too had persistent BK-virus-specific IgM responses. The geo-

\footnotetext{
Department of Virology, St Thomas's Hospital and Medical School, London SE1 7EH

AUDREY J E FLOWER, MB, DIPBACT, senior registrar (present address: Public Health Laboratory, St Luke's Hospital, Guildford, Surrey)

J E BANATVALA, MD, FRCPATH, professor of clinical virology

I L CHRYSTIE, BSC, lecturer
}

metric mean titre of BK-virus-specific IgM HAI antibody was significantly greater in post-transplantation sera $(1 / 223)$ than in control sera $(1 / 28)$. The specificity of the detection of BK-virus-specific IgM HAI antibody was confirmed by direct visualisation of antibody by immune electron microscopy. The persistence of BK-virusspecific IgM suggested that BK virus continued to provide an antigenic stimulus. Nevertheless, there was no obvious association between the serological findings and any clinical features, and prospective studies will be needed to elucidate any such association.

\section{Introduction}

BK virus was originally isolated from the urine of a patient after renal transplantation ${ }^{1}$ and is a member of the papova group of viruses. Antibodies to this virus are common in the general population, and serological studies suggest that primary infection often occurs in childhood. ${ }^{2-5}$ In England $37 \%$ of children have BK antibody by the age of 5 and this proportion has increased to $73 \%$ by the age of 10 ; a similar proportion of adults are also seropositive. ${ }^{2}$ Nevertheless, $\mathrm{BK}$ virus has been recovered only from immunocompromised patients, ${ }^{6-8}$ and virus recovery or seroconversion has not as yet been associated with any clinical features. This suggests that after primary infection BK virus may persist in a latent form but be reactivated in immunocompromised patients.

Some persistent infections in man may be associated with prolonged virus-specific IgM responses. ${ }^{9-15}$ Although BK-virusspecific IgM may be detected in patients who have had renal transplantation, ${ }^{16}$ it is not known whether it also occurs in other groups of immunocompromised patients or in apparently 